\author{
ANETA Gop \\ ORCID 0000-0002-7808-0835 \\ Centrum Nauki Kopernik \\ SYLWIA JASKULSKA \\ ORCID 0000-0002-3454-7894 \\ Uniwersytet im. Adama Mickiewicza \\ $w$ Poznaniu
}

\title{
KSZTAŁCENIE NA ODLEGŁOŚĆ A ROZWÓJ KOMPETENCJI CYFROWYCH UCZNIÓW I ICH RODZICÓW W ŚWIETLE WYNIKÓW BADAŃ - W KIERUNKU NOWEJ SZKOLY
}

\begin{abstract}
Gop Aneta, Jaskulska Sylwia, Kształcenie na odległość a rozwój kompetencji cyfrowych uczniów i ich rodziców w świetle wyników badań - w kierunku nowej szkoły [Distance Education and Students' and Parents' Digital Competencies Development in Research - Towards a New School]. Studia Edukacyjne nr 58, 2020, Poznań 2020, pp. 27-46. Adam Mickiewicz University Press. ISSN 1233-6688. DOI: $10.14746 /$ se.2020.58.2
\end{abstract}

The topic of the article is students' and their parents' digital competences development during the COVID-19 outbreak in Poland and distance learning. The text show results of two longitudinal studies: a qualitative one conducted on a group of parents of school-age children $(\mathrm{N}=89)$, and a quantitative one, with two research groups: parents of school-age children and students aged 15-18 (various N). Parents who were providing or supporting children's education during distance learning experienced digital competencies development. The main change has occurred in four areas: (1) information and data exploitation, (2) communication and (less frequently) collaboration, (3) digital content creation, and (4) problem-solving. Learning supported with digital technologies in the group of students did not change significantly, the level of digital competences remained basically at the same level, which can be explained by the high initial level of expertise. The experiences of distance education and the absent areas of the development of digital competences indicate the directions that future, modern education may follow.

Key words: distance education, digital competencies, Barents, students

\section{Wprowadzenie}

Czas pandemii COVID-19 zmienił funkcjonowanie całych społeczności w niemal wszystkich obszarach życia. Toczące się na świecie dyskusje i po- 
dejmowane badania dotyczyły przede wszystkim wymiaru zdrowotnego, związanego z bezpieczeństwem i zapewnieniem względnej stabilności gospodarczej, ale obecne były w nich także wątki technologiczne. Okazało się bowiem, że bycie online stało się $\mathrm{w}$ wielu sektorach jedyną szansą na pracę, a w edukacji - na kontynuowanie nauki. Dostęp do Internetu i sprzętu komputerowego już wcześniej różnicował ludzi. Różnice te wzmocniły się, bo kanały służące na przykład młodzieży raczej do rozrywki czy rozwijania pasji stały się obowiązkową drogą komunikacji ze szkołami. Konsekwencje wykluczenia cyfrowego stały się poważniejsze niż kiedykolwiek wcześniej.

Celem niniejszego tekstu jest ukazanie, w świetle wyników badań, zagadnienia rozwoju kompetencji cyfrowych uczniów i ich rodziców. Badania prowadzono w okresie, kiedy szkoły w Polsce były zamknięte i badane przez nas osoby doświadczały kształcenia na odległość, realizowanego w różny sposób i z różną skutecznością. Stawiamy nie tylko pytania diagnostyczne: jak uczniowie i rodzice poradzili sobie w tej sytuacji? jak można ocenić poziom ich kompetencji cyfrowych przed okresem pandemii? czy w tym obszarze nastąpiły zmiany? Zakładamy, że obserwując rozwój kompetencji cyfrowych osób tworzących szkołę (nauczycieli, dyrektorów, uczniów, rodziców), można przewidywać możliwe kierunki zmiany tej instytucji. Zmiany nie tylko wymuszone sytuacją - na przykład kolejne fale pandemii, przechodzenie w szkołach w tryb nauki zdalnej lub hybrydowej - ale także związane z tym, że następuje przesunięcie w myśleniu o kompetencjach cyfrowych i wielkościach ich zasobów.

\section{Czym są kompetencje cyfrowe?}

Zgodnie z definicją zaproponowaną przez Ministerstwo Cyfryzacji, kompetencje cyfrowe to „kompozycja wiedzy, umiejętności i postaw umożliwiających życie, uczenie się i pracę w społeczeństwie wykorzystującym technologie cyfrowe" ${ }^{\prime 1}$. Za uszczegółowienie tej definicji można uznać ujęty w ramy konceptualne zaawansowany model kompetencji cyfrowych, opisany w zaktualizowanym niedawno raporcie $\mathrm{w}$ ramach Science for Policy, opracowanym przez Joint Research Centre, które świadczy usługi naukowe w strukturach Komisji Europejskiej². Zgodnie z tym modelem, kompetencje cyfrowe dzielą się na 5 nadrzędnych obszarów, w ramach których można wyróżnić kompetencje szczegółowe. Poniższa tabela 1 zawiera definicje i sposoby ich rozumienia, podając precyzyjny obraz omawianego zagadnienia.

${ }^{1}$ Kompetencje cyfrowe, https://www.gov.pl/web/cyfryzacja/kompetencje-cyfrowe [dostęp: 12.08.2020].

${ }^{2}$ R. Vuorikari i in., DigComp 2.0: The Digital Competence Framework for Citizens. Update Phase 1: the Conceptual Reference Model; https://publications.jrc.ec.europa.eu/repository/bitstream/ JRC101254/jrc101254_digcomp \% 202.0\%20the \%20digital\%20competence $\% 20$ framework $\% 20$ for $\% 20$ citizens. \%20update\%20phase \%201.pdf [dostęp: 12.08.2020]. 
Klasyfikacja kompetencji cyfrowych

\begin{tabular}{|c|c|}
\hline $\begin{array}{c}\text { Obszary } \\
\text { kompetencji } \\
\text { Wymiar } 1\end{array}$ & $\begin{array}{l}\text { Kompetencje szczegółowe } \\
\text { Wymiar } 2\end{array}$ \\
\hline \multirow[t]{3}{*}{$\begin{array}{l}\text { 1. Wykorzy- } \\
\text { stywanie } \\
\text { informacji } \\
\text { i danych }\end{array}$} & $\begin{array}{l}\text { 1.1. Przeglądanie, wyszukiwanie i filtrowanie danych, informacji i tre- } \\
\text { ści cyfrowych } \\
\text { Wyrażanie potrzeb związanych z informacjami, wyszukiwanie da- } \\
\text { nych, informacji i treści w środowiskach cyfrowych, dostęp do nich } \\
\text { i nawigacja między nimi. Umiejętność stworzenia własnych sposobów } \\
\text { wyszukiwania informacji. }\end{array}$ \\
\hline & $\begin{array}{l}\text { 1.2. Umiejętność ocen danych, informacji i treści cyfrowych } \\
\text { Analizowanie, porównywanie i krytyczna ocena wiarygodności i rze- } \\
\text { telności źródeł danych, informacji i treści cyfrowych. }\end{array}$ \\
\hline & $\begin{array}{l}\text { 1.3. Zarządzanie danymi, informacjami i treściami cyfrowymi } \\
\text { Pozyskiwanie, organizowanie i przechowywanie danych, informacji } \\
\text { i treści online. }\end{array}$ \\
\hline \multirow[t]{6}{*}{$\begin{array}{l}\text { 2. Komu- } \\
\text { nikacja } \\
\text { i współ- } \\
\text { praca }\end{array}$} & $\begin{array}{l}\text { 2.1. Nawiązywanie interakcji z wykorzystaniem technologii cyfrowych } \\
\text { Interakcja z innymi za pomocą różnych technologii cyfrowych i zro- } \\
\text { zumienie odpowiednich środków komunikacji cyfrowej w danym } \\
\text { kontekście. }\end{array}$ \\
\hline & $\begin{array}{l}\text { 2.2. Udostępnianie treści z wykorzystaniem technologii cyfrowych } \\
\text { Udostępnianie danych, informacji i treści cyfrowych innym osobom } \\
\text { za pomocą odpowiednich narzędzi. Wiedza o tym, jak odpowiednio } \\
\text { wskazać i oznaczyć źródło udostępnionej informacji. }\end{array}$ \\
\hline & $\begin{array}{l}\text { 2.3. Obywatelskie zaangażowanie poprzez technologie cyfrowe } \\
\text { Uczestnictwo w życiu społecznym z wykorzystaniem publicznych } \\
\text { i prywatnych usług cyfrowych. Zwiększanie własnych możliwości } \\
\text { wpływu na życie społeczne poprzez odpowiednie technologie. }\end{array}$ \\
\hline & $\begin{array}{l}\text { 2.4. Współpraca z wykorzystaniem technologii cyfrowych } \\
\text { Wykorzystywanie cyfrowych narzędzi i technologii do współpracy } \\
\text { oraz do współtworzenia z innymi użytkownikami zasobów i wiedzy. }\end{array}$ \\
\hline & $\begin{array}{l}\text { 2.5. Netykieta } \\
\text { Swiadomość norm zachowania podczas korzystania z technologii } \\
\text { cyfrowych i interakcji w środowisku cyfrowym. Dostosowywanie } \\
\text { sposobu komunikowania się do konkretnych odbiorców. Świadomość } \\
\text { różnorodności kulturowej i pokoleniowej w środowiskach cyfrowych. }\end{array}$ \\
\hline & $\begin{array}{l}\text { 2.6. Zarządzanie cyfrową tożsamością } \\
\text { Tworzenie i zarządzanie jedną lub wieloma tożsamościami cyfrowymi, } \\
\text { aby móc chronić swój wizerunek. Świadomość danych, które wytwa- } \\
\text { rzanych za pomocą cyfrowych narzędzi, środowisk i usług. }\end{array}$ \\
\hline $\begin{array}{l}\text { 3. Tworzenie } \\
\text { treści cy- } \\
\text { frowych }\end{array}$ & $\begin{array}{l}\text { 3.1. Rozwijanie treści cyfrowych } \\
\text { Tworzenie i edytowanie treści cyfrowych w różnych formatach, wyra- } \\
\text { żanie siebie za pomocą technologii cyfrowej. }\end{array}$ \\
\hline
\end{tabular}




\begin{tabular}{|c|c|}
\hline \multirow[t]{3}{*}{$\begin{array}{l}\text { 3. Tworzenie } \\
\text { treści } \\
\text { cyfrowych }\end{array}$} & $\begin{array}{l}\text { 3.2. Gromadzenie i ponowne przetwarzanie zasobów cyfrowych } \\
\text { Modyfikowanie, udoskonalanie, ulepszanie i integrowanie informacji } \\
\text { i materiałów z istniejącym zasobem wiedzy w celu wytworzenia no- } \\
\text { wych, oryginalnych i istotnych treści oraz wiedzy. }\end{array}$ \\
\hline & $\begin{array}{l}\text { 3.3. Prawa autorskie i licencje } \\
\text { Zrozumienie, jak prawa autorskie i licencje mają zastosowanie do da- } \\
\text { nych, informacji i zasobów cyfrowych. }\end{array}$ \\
\hline & $\begin{array}{l}\text { 3.4. Programowanie } \\
\text { Planowanie i rozwijanie sekwencji zrozumiałych instrukcji dla syste- } \\
\text { mu informatycznego w celu rozwiązania danego problemu lub wyko- } \\
\text { nania określonego zadania. }\end{array}$ \\
\hline \multirow[t]{4}{*}{$\begin{array}{l}\text { 4. Bezpie- } \\
\text { czeństwo }\end{array}$} & $\begin{array}{l}\text { 4.1. Ochrona urządzeń } \\
\text { Ochrona urządzeń i treści cyfrowych oraz zrozumienie ryzyka i za- } \\
\text { grożeń istniejących w środowisku cyfrowym. Wiedza o środkach } \\
\text { bezpieczeństwa i ochrony oraz należyty wgląd w wiarygodność i pry- } \\
\text { watność. }\end{array}$ \\
\hline & $\begin{array}{l}\text { 4.2. Ochrona danych osobowych i prywatności } \\
\text { Ochrona danych osobowych w środowisku cyfrowym, zrozumienie } \\
\text { sposobu wykorzystania i udostępniania identyfikowalnych danych } \\
\text { osobowych, będąc jednocześnie w stanie chronić siebie i innych przed } \\
\text { szkodami. Zrozumienie sposobu wykorzystania przez serwisy interne- } \\
\text { towe "Polityki prywatności", która polega na informowaniu o sposo- } \\
\text { bach wykorzystania danych personalnych. }\end{array}$ \\
\hline & $\begin{array}{l}\text { 4.3. Ochrona zdrowia i dobrostanu psychologicznego (ang. well-being) } \\
\text { Zdolność do unikania zagrożeń dla zdrowia fizycznego i psychicznego } \\
\text { podczas korzystania z technologii cyfrowych. Zdolność do ochrony } \\
\text { siebie i innych przed możliwymi niebezpieczeństwami w środowisku } \\
\text { cyfrowym (np. cybernękanie, ang. cyber bullying). Świadomość istnie- } \\
\text { nia technologii cyfrowych służących dobrobytowi społecznemu i inte- } \\
\text { gracji społecznej. }\end{array}$ \\
\hline & $\begin{array}{l}\text { 4.4. Ochrona środowiska } \\
\text { Świadomość wpływu technologii cyfrowych i ich wykorzystania na } \\
\text { środowisko. }\end{array}$ \\
\hline \multirow[t]{3}{*}{$\begin{array}{l}\text { 5. Rozwiązy- } \\
\text { wanie pro- } \\
\text { blemów }\end{array}$} & $\begin{array}{l}\text { 5.1. Rozwiązywanie problemów technicznych } \\
\text { Identyfikowanie problemów technicznych podczas obsługi urządzeń } \\
\text { i korzystania z platform cyfrowych oraz ich rozwiązywanie (od roz- } \\
\text { wiązywania prostych problemów po rozwiązywanie bardziej złożo- } \\
\text { nych kwestii). }\end{array}$ \\
\hline & $\begin{array}{l}\text { 5.2. Identyfikacja potrzeb } \\
\text { Dostosowywanie platform i usług cyfrowych do własnych potrzeb. }\end{array}$ \\
\hline & $\begin{array}{l}\text { 5.3. Kreatywne wykorzystanie technologii cyfrowych } \\
\text { Wykorzystywanie narzędzi i technologii cyfrowych do tworzenia } \\
\text { wiedzy, innowacji, nowych rozwiązań. Rozumienie i rozwiązywanie } \\
\text { problemów na platformach cyfrowych. }\end{array}$ \\
\hline
\end{tabular}


5.4. Identyfikacja braków w kompetencjach cyfrowych Identyfikacja luk we własnych kompetencjach. Bieżące aktualizowanie własnej wiedzy. Szukanie możliwości samorozwoju.

Źródło: R. Vuorikari i in., DigComp 2.0: The Digital Competence Framework for Citizens. Update Phase 1: the Conceptual Reference Model, 2016, s. 8-9: https://publications.jrc.ec.europa.eu/repository/bitstream/ JRC101254/jrc101254_digcomp\%202.0\%20the\%20digital\%20competence $\% 20$ framework $\% 20$ for $\% 20$ citizens.\%20update\%20phase\%201.pdf [dostęp: 12.08.2020].

Klasyfikacja ta posłuży jako narzędzie kategoryzacji danych jakościowych uzyskanych podczas badania podłużnego, prowadzonego w okresie 15.0426.06.2020, którego celem było między innymi określenie zmian w zakresie kompetencji cyfrowych $\mathrm{w}$ grupie rodziców wspomagających uczenie się zdalne dzieci w czasie przejścia szkół w tryb kształcenia na odległość, w związku z pandemią COVID-19. Zidentyfikowanie wypowiedzi budujących kategorie szczegółowe powyższej klasyfikacji nakreśli obszary i kierunki, w których rozwijały się kompetencje cyfrowe $\mathrm{w}$ badanej grupie. Tym samym, uwidocznią się także elementy kompetencji, które nie zostały rozwinięte. Na podstawie tych danych oraz informacji dostarczonych przez ilościowe badanie kompetencji cyfrowych zostaną sformułowane wnioski, które mogą stać się głosem $\mathrm{w}$ dyskusji nad pożądanym kierunkiem zmian szkolnictwa.

\section{Rozwój kompetencji cyfrowych. Analizowane badania}

W artykule zostaną szczegółowo zanalizowane wyniki dwóch badań przeprowadzonych przez Centrum Nauki Kopernik, we współpracy z Ogólnopolskim Panelem Badawczym Ariadna.

Pierwsze realizowano w okresie 15.04-26.06.2020 roku. Było to badanie podłużne przeprowadzone na grupie rodziców, którzy sprawowali opiekę nad dziećmi w czasie nauki zdalnej. Jego celem było uchwycenie praktyk i doświadczeń edukacyjnych dzieci widzianych oczyma rodziców. Rodzice byli proszeni o opisanie $\mathrm{w}$ dziennikach ${ }^{3}$ osobistych praktyk, doświadczeń i pojawiających się problemów związanych z uczeniem się swojego dziec$\mathrm{ka}^{4}$. Prosiliśmy rodziców także, aby przyjrzeli się technologiom, z jakich ko-

${ }^{3}$ Dzienniczki stanowią jedno z narzędzi pomiaru bezpośredniego doświadczenia jednostek. Podczas korzystania $\mathrm{z}$ nich gromadzi się narracje prowadzone $\mathrm{w}$ pierwszej osobie, wypowiedzi autorefleksyjne, wartościujące, subiektywne opisy praktyk. Por. M.B. Kielar, A. Gop, Integralny Pluralizm Metodologiczny. Teoria i badania naukowe, Warszawa 2012.

${ }^{4}$ Wyniki tego badania szerzej przedstawiono w artykule: M. Łukianow, A. Gop, J. Skrzypowska, Rodzicielskie doświadczenia nauczania zdalnego w okresie pandemii COVID-19, Kultura i Społeczeństwo ( $w$ druku). 
rzystają w codziennej pracy z dzieckiem oraz zmianom towarzyszącym ich wykorzystaniu. Pomiaru dokonano czterokrotnie w różnych odstępach czasu (1. dzienniczek: 15 kwietnia, 2. dzienniczek: 22 kwietnia, 3. dzienniczek: 29 kwietnia, 4 . dzienniczek: 26 czerwca).

Badanie przeprowadzono na próbie ogólnopolskiej, z zastosowaniem doboru celowego. Udział w nim wzięło 89 respondentów $(\mathrm{N}=89) .70 \% \mathrm{z}$ nich ma dwoje dzieci w wieku szkolnym (7-15 lat), 26\% posiadało trójkę dzieci. $53 \%$ badanych stanowiły kobiety. Najliczniejszą grupą badanych byli mieszkańcy wsi (43\%), najmniejszą zaś - respondenci średnich miast, do 100 tys. mieszkańców (8\%).

Drugie badanie zrealizowano w kwietniu - lipcu 2020 roku. Było to badanie ilościowe dotyczące edukacji w czasie epidemii. Jego cel polegał na uchwyceniu zmian w użyciu technologii w uczeniu się. Próba objęła rodziców dzieci w wieku szkolnym, studentów oraz 15-18-letnich uczniów. W tekście przywołujemy jedynie wyniki dotyczące rodziców i uczniów. Badanie przeprowadzono na quasi-reprezentatywnej ${ }^{5}$ próbie internetowej i obejmowało pokrywające się zbiory respondentów (por. tab. 2).

Tabela 2

Liczebności poszczególnych grup z podziałem na pomiary

\begin{tabular}{|l|c|c|}
\hline \multicolumn{1}{|c|}{ Grupa badana } & $\begin{array}{c}\text { Liczebność - I. pomiar } \\
\text { (kwiecień 2020) }\end{array}$ & $\begin{array}{c}\text { Liczebność - II. pomiar } \\
\text { (czerwiec-lipiec 2020) }\end{array}$ \\
\hline Uczniowie (15-18 lat) & 304 & 190 \\
\hline Studenci & 320 & 224 \\
\hline $\begin{array}{l}\text { Rodzice dzieci } \\
\text { w wieku szkolnym }\end{array}$ & 620 & 512 \\
\hline
\end{tabular}

Źródło: opracowanie własne.

Badani udzielili odpowiedzi na nieco ponad 20 pytań, które dotyczyły głównie: a) sposobu i form kontaktu z grupą/klasą oraz szkołą/uczelnią, b) stosowanych w nauce rozwiązań technologicznych, c) sposobu pozyskiwania i rodzaju materiałów do nauki, d) sposobów i rodzajów uczenia się, w tym czasu poświęcanego nauce oraz organizacji pracy własnej, e) obaw i zysków związanych z nauczaniem zdalnym.

${ }^{5}$ Reprezentatywność próby w tym badaniu nie jest pełna, ponieważ badanie nie dotarło do osób nie mających dostępu do Internetu. Zastosowano dobór kwotowy. 


\section{Ogólna ocena i samoocena kompetencji cyfrowych. Perspektywa rodziców [badanie jakościowe i ilościowe]}

Na oszacowanie poziomu kompetencji cyfrowych przez rodziców patrzono z dwóch perspektyw. W pierwszym ujęciu rodzic oceniał własne umiejętności cyfrowe (dzienniczki) ${ }^{6}$, w drugim - umiejętności dziecka (ankieta).

W pierwszym pomiarze rodzice deklarowali równie często, że nie mają problemu z wykorzystaniem technologii (29\%), jak również, że po ponad miesiącu korzystania z technologii cyfrowych ${ }^{7}$ jest im zdecydowanie łatwiej wykorzystywać narzędzia technologiczne (28\%). W końcowym pomiarze, który miał miejsce 26 czerwca 2020 roku (zakończenie roku szkolnego 2019/2020), zdecydowaną łatwość w obsłudze programów deklarowało już 43\% rodziców:

Tak, uważam, że wraz z mijającym czasem i koniecznością korzystania z nowych technologii (e-learning, chaty online, czy e-kursy) robie się coraz bardziej biegła w tej dziedzinie. Korzystanie z nowych alternatyw nie tylko mnie cieszy, ale też dowartościowuje, bo nie sądziłam, że będę w stanie w tak szybkim czasie to wszystko opanować $[62 ; 4]^{8}$.

Teraz opanowane mamy takie programy, jak Teams, potrafimy szybko i sprawnie poruszać się w tym środowisku. Nie mamy problemów z komunikacja z nauczycielami i kolegami oraz koleżankami. Pod tym względem jest bardzo duży progres w stosunku do pierwszych dni zdalnej edukacji. Jeśli chodzi o tego typu kompetencje, to syn zrobił bardzo duże postępy [64; 4].

Można zatem stwierdzić, że w opinii prawie połowy rodziców nastąpił ogólny wzrost kompetencji cyfrowych.

Niektórym rodzicom nie jest jednak łatwo korzystać z nowych technologii - niespełna 9\% w pierwszym pomiarze oraz 7\% w ostatnim zadeklarowało brak nabycia wprawy w tym zakresie. Powody tej sytuacji bywają różne:

Nie jest mi łatwiej, nauczyciele każa przesyłać niektóre pliki ze sprawdzianami, kartkówkami czy zadaniami tekstowymi do siebie poprzez różne pliki, które sa ciężkie dla mnie do ogarnięcia [42; 1].

\footnotetext{
${ }^{6}$ Pojawiające się w dzienniczkach wpisy dotyczące także kompetencji cyfrowych dziecka, przeplatały się z samooceną własnych kompetencji.

7 Pierwszy pomiar wykonano po około miesiącu od momentu zamknięcia szkół, tj. 12 marca 2020.

${ }^{8}$ Cytaty po korekcie językowej. Symbole w nawiasie kwadratowym oznaczają kolejno: numer respondenta $\mathrm{w}$ bazie i numer wpisu.
} 
Nie jest mi wcale łatwo, nie jestem z komputerem, nowinkami technicznymi za pan brat. Znam obstuge komputera stacjonarnego tylko w podstawowym zakresie, bo za moich czasów szkolnych nie było ani komputerów, ani zajęć z obstugi komputera - tak zwanych zajęć informatycznych. Więc jak mam swojemu dziecku pomóc? $[53 ; 1]$.

Nie jest łatwiej, ponieważ sprzęt, który mamy w domu, jest już wiekowy i ciężko się na nim pracuje, więc lekcje online bytyby udręka [28;3].

Część badanych rodziców unikała oceny własnych kompetencji w zakresie wykorzystania nowych technologii, koncentrując się we wpisach na zaletach i wadach wykorzystywanych narzędzi:

Jak pisałam, najlepszy jest Skype i Messenger. Librus, wedtug mnie, tylko do sprawdzania wyników. Dzieci musza w konkretnych godzinach "być na zajęciach", bo inaczej gubia rytm i niekoniecznie same potrafia ustalić sobie tak plan dnia, aby wykorzystać ten czas maksymalnie [2; 1].

Połaczenie z Internetem jest niezbędne do nauki zdalnej, platformy edukacyjne także sa ułatwieniem w tej kwestii. Komunikacja poprzez maila i aplikacja Discord umożliwiaja szybka komunikacje całej klasy z nauczycielami. Sieć internetowa to jedyne stuszne rozwiazanie w obecnej sytuacji i zapobiegnie wydłużeniu roku szkolnego $[40 ; 1]$.

$\mathrm{W}$ badaniu ilościowym ankietowanym rodzicom dwukrotnie zadano pytanie, co według nich dziecko zyskuje dzięki korzystaniu z technologii w uczeniu się po zamknięciu szkół ${ }^{9}$. Odpowiedzi na nie dają obraz tego, jak zdaniem rodziców wykorzystanie technologii służy wzrostowi kompetencji w zakresie wykorzystania technologii w celowy, sprzyjający nabywaniu wiedzy i umiejętności, sposób. Jedna czwarta ${ }^{10}$ badanych rodziców stwierdziła, że dzięki wykorzystaniu technologii w uczeniu się dziecko rozwija kompetencje posługiwania się komputerem/smartfonem/tabletem ${ }^{11}$. Opinia ta utrzymywała się $w$ tym czasie na stałym poziomie, to jest nie zmieniła się wraz z wydłużającym się doświadczeniem kształcenia zdalnego.

Ocena rozwoju kompetencji cyfrowych w sytuacji przymusu odbywania edukacji zdalnej w badaniu jakościowym (samoocena) i ilościowym (ocena funkcjonowania dziecka) jest różna. Różnice te można postrzegać jako wy-

${ }_{9}^{9}$ Na etapie analizy danych za istotne uznano zmiany większe od 5\%, czyli różnice między pomiarami większe niż pięcioprocentowy błąd pomiaru.

${ }_{10} 25 \% \mathrm{w}$ pierwszym pomiarze, $23 \% \mathrm{w}$ drugim pomiarze.

${ }^{11}$ Jedynie $5 \%$ rodziców w pierwszym, a $8 \%$ w drugim pomiarze obawiało się obniżenia tych kompetencji. 
nik obranej perspektywy oceniania. U rodziców wypełniających dzienniczki samoocena formułowana jest na podstawie pogłębionej analizy własnych doświadczeń, u rodziców badanych ankietowo ocena ta dotyczy nie ich samych, a dzieci i może być dokonywana w odniesieniu do innych osób lub postawy względem całokształtu edukacji zdalnej.

Ocena tego, jak radziły sobie dzieci być może była zarazem oceną całokształtu edukacji zdalnej. Jeśli mamy tu do czynienia z projektowaniem niezadowolenia na działanie systemu lub konkretnych nauczycieli na odpowiedzi $w$ badaniu, a jest to jeden $z$ kierunków interpretacyjnych, to zjawisko to raczej ma szansę zaistnieć w części ankietowej, niż w dzienniczkach. Dokonywana samoocena trochę bardziej, niż ocena funkcjonowania dziecka, oderwana jest od kontekstu samej szkoły i jej działań. Inny kierunek interpretacji może dotyczyć tego, że kompetencje cyfrowe dzieci były wyjściowo wyższe, niż rodziców. Oczywiście są i uczniowie, którzy wcale w tych technologiach nie byli bardzo obeznani, są też rodzice świetnie się nimi posługujący. Tendencja jest jednak na korzyść młodszych. Badania prowadzone na reprezentatywnej próbie 5000 uczniów pokazują, że przed czasem pandemii nowe technologie były dla $52 \%$ badanych bardzo ważne i bardzo się nimi interesowali, 32\% często z nich korzystało, choć nie były one dla nich aż tak ważne ${ }^{12}$.

Zatem, 85\% uczniów i uczennic przechodząc w marcu na zdalną formę edukacji, dysponowało wysokimi kompetencjami cyfrowymi, a przynajmniej tak je ocenia. Być może dlatego w ich przypadku dostrzegany przez rodziców wzrost kompetencji cyfrowych nie jest aż tak duży.

\section{Rozwój szczegółowych kompetencji cyfrowych. Perspektywa rodziców [badanie jakościowe]}

Analizie poddano wszystkie wypowiedzi respondentów z narracji prowadzonych na przestrzeni czterech pomiarów. Szukano wpisów świadczących o przejawach uruchomienia czy rozwoju kompetencji szczegółowych z perspektywy badanej osoby. Wpisy dotyczyły zarówno kompetencji rodzica, jak i dziecka, a pojawiały się i takie, które zobrazowały kompetencje cyfrowe nauczycieli.

Kompetencje cyfrowe $\mathrm{w}$ perspektywie rodziców rozwijały się głównie w czterech obszarach, to jest (1) wykorzystywania informacji i danych, (2) komunikacji i (rzadziej) współpracy, (3) tworzenia treści cyfrowych oraz (4) rozwiązywania problemów.

${ }^{12} \mathrm{H}$. Krauze-Sikorska i in., Twoja lekcja w przyszłości. Jak wyobrażasz sobie naukę w szkole po pandemii COVID-19? Raport z badania ankietowego; https://sites.google.com/view/twoja-lekcja -w-przyszlosci [dostęp: 09.09.2020]. 
1. W zakresie wykorzystywania informacji i danych narracje ogniskowały się głównie wokół przeglądania i wyszukiwania informacji cyfrowych, bez informacji odnośnie analizowania treści, czy krytycznej oceny źródeł, czy sposobu organizowania i przechowywania danych:

W tym tygodniu poświęcaliśmy na naukę około dwóch godzin, szukając informacji do nauki przez Internet [1; 7].

Żadnych trudności nie dostrzegam, ponieważ wszystkie potrzebne materiaty i pomoce naukowe sa dostępne w domu lub można korzystać z zasobów zgromadzonych w Internecie. Jedynie można mieć watpliwości co do wiedzy zdobytej podczas takiej zdalnej nauki [10; 11].

Doszkala się ogladając materiały na YouTubie bądź korzysta z innych stron, aby lepiej zrozumieć dany temat $[13 ; 1]$.

Córka spędzała pół dnia przed monitorem, dodatkowo wyszukiwała materiaty i filmy instruktażowe na różnych stronach, np. YouTubie [13; 10].

2. W zakresie komunikacji i współpracy pojawiają się wpisy dotyczące interakcji z innymi, z wykorzystaniem różnych technologii cyfrowych i środków komunikacji. Rodzice relacjonowali, jakie narzędzia do pracy online wykorzystują lub formułowali oceny w zakresie tego, które narzędzie sprawdza się i w jakim obszarze:

1 liceum: Librus: osobiście nie lubię tej metody, bo to tylko zadawanie i sprawdzanie zadań domowych. Córka mniej spędza czasu na telefonie, ale traci kontakt $z$ nauczycielami, sama musi organizować sobie czas, a różne sa tego skutki. Ponadto uważam, że jest to narzędzie do kontroli, a nie do pracy zdalnej z uczniem. 7 klasa: świetna organizacja - Messenger. Bezpośredni kontakt z nauczycielem, syn ma ustalone godziny (taki plan lekcji) przedmiotów i ma kontakt $z$ nauczycielem, przynajmniej z jego głosem, ale prowadza rozmowy $i$ jest to przyjemne, i nie traci kontaktu. Ma ustalone, ile czasu musi poświęcić na naukę - jest organizacja. 3 klasa: Messenger i Skype - też super. Bezpośredni kontakt, praca w określonych godzinach - organizacja i bezpośredni kontakt. Świetna sprawa, dziecko nie wychodzi z rytmu szkolnego [2; 4].

Wpisy dotyczą także udostępniania treści cyfrowych (głównie prac domowych), bez informacji odnośnie oznaczania źródeł udostępnionych informacji. Treści cyfrowe będące dokumentacją pracy domowej mogły nie wymagać od dziecka i rodzica wiedzy oraz praktyki w zakresie oznaczania źródła: 
Wostatnim tygodniu nie potrzebowat już pomocy przy odsyłaniu zdjęć zeszytów i ćwiczeń nauczycielom na platformę Google Classroom. Sam obstuguje i platforme, i swojego Gmaila stworzonego do pracy szkolnej. Bez większych trudności mieści się w czasie lekcyjnym - na zrobienie zadanej pracy, jak i jej odesłanie do sprawdzenia. Bez żadnej pomocy wykonuje na platformie kartkówki i sprawdziany [7; 7].

W kontekście uczestnictwa w życiu społecznym pojawiają się wpisy świadczące o wykorzystaniu usług cyfrowych w zakresie kontaktów dzieci z kolegami z klasy, spotkaniach ze szkoła, z innymi rodzicami, czy ze znajomymi:

(...) następnym to oczywiście taczenie się $z$ rodzina lub znajomymi $z a$ pomoca komunikatorów internetowych $[11 ; 6]$.

W narracjach rodziców sporadycznie pojawiają się wpisy dotyczące wykorzystywania technologii do współpracy:

Po otrzymaniu zadania, dziecko z pomoca Internetu je odrabiało i czasem łaczyto się przez Skype'a ze swoimi kolegami i koleżankami z klasy, konsultując zadania i odpowiedzi $[29 ; 4]$.

3. W zakresie tworzenia treści cyfrowych pojawiają się jedynie wpisy dotyczące tworzenia lub edytowania treści (prac domowych, sprawdzianów) $\mathrm{i}$ ich odesłania na maila, często w postaci zdjęcia pracy:

Różne formaty przesyłanych materiatów, różne formy realizacji zadań i przesytania rezultatów - brak jest danych co do sposobu tworzenia i przekształcania treści; $w$ zależności od formy polecenia mogły być to: proste wykonanie zadania lub napisanie rozprawki [8; 2].

4. W zakresie rozwiązywania problemów pojawiają się ogólne wpisy dotyczące rozwiązywania prostych problemów technicznych:

Na początku miatem duże problemy, nie mogliśmy brać udziatu w lekcjach, bo albo nie było można się połaczyć, albo nie było nic słychać ani widać. Zajęło to nam dużo, nawet bardzo dużo czasu, żeby to ogarnąć, ale wreszcie nam się udało i już wszystko jest w porządku [11;8].

Rodzice identyfikują braki w zakresie własnych kompetencji cyfrowych:

Trudności sa takie same, jakie byly od początku, to jest zwiazane z techniczna obstuga Google Classrooma. Syn dalej nie zna wszystkich funkcji. Korzysta 
tylko z czatu i zadań, które ma do oddania. Nie umie korzystać z tworzenia w tym programie dokumentów lub ich modyfikacji. Nauczyłam dziecko w tym tygodniu wysyłania zdjęć na komputer, żeby mógł je wysyłać do sprawdzenia nauczycielom $[7 ; 5]$.

Choć obecnie z powodu pracy i nauki $w$ domu poznaję sporo nowych technologii oraz funkcji, urządzeń, $z$ których często korzystałem, a nie byłem świadomy, że można $z$ ich pomoca robić sporo innych rzeczy. Jest to idealny czas do nauki i trenowania $[9 ; 3]$.

W tym momencie córka i ja mamy opanowana wręcz do perfekcji umiejętność posługiwania się laptopem. Wcześniej osobiście byt mi tylko potrzebny w niewielkim stopniu, a tu nagle nauczanie zdalne. Trzeba było nauczyć się obstugi nie jednego programu i to w sumie bez żadnej pomocy z zewnątrz, ale metoda prób i błędów. Jakoś nam się udało [11; 12].

Przymus edukacji zdalnej unaocznił braki w zakresie kompetencji cyfrowych, które niwelowane były przez trening, uczenie się wspólne z dzieckiem lub od dziecka. Zdarzało się, że dziecko wymagało nauki obsługi programów, wówczas to rodzic wprowadzał je w arkana korzystania z narzędzi cyfrowych.

W narracjach rodziców nie ma wpisów dotyczących obszaru bezpieczeństwa (ochrony urządzeń, danych osobowych i prywatności, dobrostanu psychologicznego, czy środowiska). Brakuje również wypowiedzi, w których poruszana byłaby tematyka z dziedziny praw autorskich, współtworzenia zasobów i wiedzy z innymi użytkownikami (pracy projektowej). Nieobecna jest netykieta, zarządzanie cyfrową tożsamością. Brak jest informacji o zakresie gromadzenia i przetwarzania zasobów cyfrowych, rozumienia praw autorskich i licencji, lub wykorzystania umiejętności programowania. Nie ma także wpisów odnośnie rozwiązywania problemów w dziedzinie identyfikacji potrzeb (dostosowywania usług do własnych potrzeb), kreatywnego wykorzystania technologii cyfrowych. Może mieć to związek z przyjętą metodą pomiaru ${ }^{13}$, która pozwala na sformułowanie dwojakiego rodzaju wniosków: nieobecność niektórych obszarów można wiązać z tym, że rodzice nie doświadczali tego rodzaju problemów, ale mogli także doświadczając ich w niewielkim zakresie, nie przypisywać im dużej wagi, lub też nie identyfikować ich jako problem i dlatego ich nie opisali.

${ }^{13}$ Badanie pozwalało na prowadzenie swobodnej narracji, a więc pomiar był mało dokładny (nie zadano wprost pytania o te obszary). 


\section{Rozwój szczegółowych kompetencji cyfrowych. Perspektywa uczniów [badanie ilościowe]}

W badaniach ilościowych, w których ankietowani byli uczniowie (15-18 lat), wyłoniono obszary dotyczące szczegółowych kompetencji cyfrowych.

Na przykład, w zakresie przeglądania, wyszukiwania i filtrowania danych, informacji i treści cyfrowych (wymiar 1: wykorzystywanie informacji i danych) wykazano, że uczniowie rzadziej korzystają z materiałów przesyłanych im przez nauczycieli oraz kolegów/koleżanki; więcej osób zaczęło korzystać z portali edukacyjnych, rezygnując ze źródeł typu YouTube (por. tab. 3 i 4).

Rozkład odpowiedzi na pytanie:

Tabela 3

"Skąd czerpiesz materiały do nauki odkąd zamknięto szkoły?"

Odpowiedzi "tak” (uczniowie)

\begin{tabular}{|l|c|c|}
\hline \multicolumn{1}{|c|}{$\begin{array}{c}\text { Skąd czerpiesz materiały } \\
\text { do nauki, odkąd zamknięto } \\
\text { szkoły? }\end{array}$} & I. pomiar & $\begin{array}{c}\text { II. pomiar } \\
\text { - zmiana względem } \\
\text { pomiaru I. }\end{array}$ \\
(zmiana podłużna)
\end{tabular}

Źródło: opracowanie własne. 
Rozkład odpowiedzi na pytanie:

Tabela 4

"Z jakich materiałów, zajęć i zadań edukacyjnych korzystałaś/eś?"

Odpowiedzi „,tak”, tylko pierwszy pomiar (uczniowie)

\begin{tabular}{|l|c|c|c|}
\hline $\begin{array}{l}\text { Z jakich materiałów, zajęć i zadań } \\
\text { edukacyjnych korzystałaś/eś? }\end{array}$ & $\begin{array}{c}\text { Przed } \\
\text { zamknięciem }\end{array}$ & $\begin{array}{c}\text { Dopiero } \\
\text { teraz }\end{array}$ & Nigdy \\
\hline $\begin{array}{l}\text { Materiały szkolne, przesyłane } \\
\text { elektronicznie przez nauczycieli } \\
\text { lub wykładowców }\end{array}$ & $34,21 \%$ & $73,68 \%$ & $2,30 \%$ \\
\hline $\begin{array}{l}\text { Materiały udostępniane przez } \\
\text { nauczycieli z innych szkół }\end{array}$ & $25,33 \%$ & $35,86 \%$ & $43,75 \%$ \\
\hline $\begin{array}{l}\text { Materiały udostępniane przez } \\
\text { muzea i centra nauki }\end{array}$ & $15,13 \%$ & $25,66 \%$ & $61,84 \%$ \\
\hline $\begin{array}{l}\text { Materiały edukacyjne na YouTu- } \\
\text { bie, webinaria, kursy }\end{array}$ & $58,22 \%$ & $43,09 \%$ & $10,06 \%$ \\
\hline $\begin{array}{l}\text { Materiały edukacyjne na specjal- } \\
\text { nych portalach }\end{array}$ & $33,88 \%$ & $54,28 \%$ & $19,41 \%$ \\
\hline $\begin{array}{l}\text { Zajęcia wymyślane dla mnie } \\
\text { przez członków rodziny }\end{array}$ & $17,43 \%$ & $16,78 \%$ & $68,42 \%$ \\
\hline
\end{tabular}

Źródło: opracowanie własne.

Chociaż uzyskane dane nie mówią, czym uczniowie zastępują materiały przesyłane przez nauczycieli, to uwidacznia się tendencja ku stopniowemu uniezależnianiu się od informacji pozyskiwanych z jednego źródła.

W dziedzinie nawiązywania interakcji z wykorzystaniem technologii cyfrowych (wymiar 2: komunikacja i współpraca) odnotowano fakt, że większość uczniów uczy się indywidualnie, samodzielnie (niemal 9. na 10. badanych uczniów i uczennic), a sposób komunikacji z klasą nie ulega istotnym zmianom na przestrzeni czasu (por. tab. 5).

Tabela 5

Rozkład odpowiedzi na pytanie:

„W jaki sposób kontaktujesz się ze swoją klasą po zamknięciu szkoły?”

Odpowiedzi „tak” (uczniowie)

\begin{tabular}{|c|c|c|}
\hline $\begin{array}{c}\text { W jaki sposób kontaktujesz się ze swoją klasą } \\
\text { po zamknięciu szkoły? }\end{array}$ & I. pomiar & $\begin{array}{c}\text { II. pomiar } \\
- \text { zmiana względem } \\
\text { pomiaru I. } \\
\text { (zmiana podłużna) }\end{array}$ \\
\hline Przez dziennik elektroniczny & $11,18 \%$ & $12,11 \%$ \\
& $+0,93$ \\
\hline
\end{tabular}




\begin{tabular}{|l|c|c|}
\hline $\begin{array}{l}\text { Nieformalna grupa klasowa na Messenge- } \\
\text { rze/WhatsAppie itp. }\end{array}$ & $73,68 \%$ & $\begin{array}{l}71,05 \% \\
-2,63 \%\end{array}$ \\
\hline $\begin{array}{l}\text { Grupa klasowa zorganizowana przez na- } \\
\text { uczyciela, np. na Google Classroom }\end{array}$ & $25,99 \%$ & $\begin{array}{c}27,89 \% \\
+1,9 \%\end{array}$ \\
\hline $\begin{array}{l}\text { Kontakt przez komunikatory z poszczegól- } \\
\text { nymi kolegami z klasy, organizowany przez } \\
\text { samych uczniów }\end{array}$ & $45,72 \%$ & $48,42 \%$ \\
& & $+2,7 \%$ \\
\hline Indywidualne rozmowy telefoniczne z na- & $4,28 \%$ & $8,42 \%$ \\
uczycielem & & $+4,14 \%$ \\
\hline Indywidualne rozmowy telefoniczne z kole- & $34,21 \%$ & $29,47 \%$ \\
gami z klasy & & $-4,74 \%$ \\
\hline Inny sposób & $1,32 \%$ & $0,53 \%$ \\
& & $-0,79 \%$ \\
\hline Nie mam żadnej możliwości kontaktu z klasą & $2,96 \%$ & $3,68 \%$ \\
& & $+0,72$ \\
\hline
\end{tabular}

Źródło: opracowanie własne.

Brak zmian w tym zakresie może wskazywać, że wykorzystywanie dostępnych form, metod i narzędzi pracy ustabilizowało się na przestrzeni czasu. Interesujące jest, że najbardziej popularną formą kontaktu wśród uczniów (niemal $3 / 4$ respondentów) jest korespondencja między członkami nieformalnie utworzonej grupy oraz indywidualny kontakt przez komunikatory z rówieśnikami. Bliżej końca roku szkolnego spada częstość kontaktów z rówieśnikami na korzyść zwiększenia indywidualnych rozmów z nauczycielem. Może to wiązać się z faktem, że w miarę upływu czasu szkoły wypracowały sposoby radzenia sobie i ten kontakt był przez nie także inicjowany. Wzrost ten można też tłumaczyć zbliżającym się końcem roku szkolnego, a więc konieczności uzyskania oceny końcowej z przedmiotów.

Przyglądając się aspektowi współpracy z wykorzystaniem narzędzi cyfrowych (por. tab. 6), można zaobserwować, że pod koniec roku szkolnego uczniowie rzadziej uczyli się samodzielnie, nieco częściej korzystali z pomocy osób dorosłych. Co czwarty uczeń i uczennica uczą się wspólnie z kolegami z klasy. Na przestrzeni czasu w tym wymiarze nie zaszły znaczące zmiany. Możliwe kierunki interpretacji dotyczą dwóch aspektów: 1) ograniczonej możliwości zdalnej pracy grupowej - nauczyciele zadawali głównie prace indywidualne, nie wykorzystując możliwości zadania prac grupowych, projektowych oraz 2) okres pandemii i izolacji nie wytworzył nowych form kontaktu między uczniami, utrzymały się raczej te już istniejące. 
Rozkład odpowiedzi na pytanie:

Tabela 6

"Z kim uczysz się odkąd zamknięto szkoły?"

Odpowiedzi „tak” (uczniowie)

\begin{tabular}{|l|c|c|}
\hline \multicolumn{1}{|c|}{$\begin{array}{c}\text { Z kim uczysz się } \\
\text { odkąd zamknięto szkoły? }\end{array}$} & I. pomiar & $\begin{array}{c}\text { II. pomiar - zmiana } \\
\text { względem pomiaru I. } \\
\text { (zmiana podłużna) }\end{array}$ \\
\hline Indywidualnie wykonuję zadania & $89,14 \%$ & $83,68 \%$ \\
& & $-5,46 \%$ \\
\hline $\begin{array}{l}\text { Z kolegami - uczymy się razem } \\
\text { korzystając z Internetu }\end{array}$ & $23,36 \%$ & $23,68 \%$ \\
& & $+0,32$ \\
\hline Z dorosłymi, którzy są w domu & $6,91 \%$ & $10 \%$ \\
& & $+3,09$ \\
\hline Z rodzeństwem & $8,22 \%$ & $9,47 \%$ \\
& & $+1,25 \%$ \\
\hline Inaczej & $1,97 \%$ & $1,05 \%$ \\
& & $-0,92 \%$ \\
\hline
\end{tabular}

Źródło: opracowanie własne.

W dziedzinie dostosowywania platform i usług cyfrowych do własnych potrzeb (wymiar 5: rozwiązywanie problemów) uwidoczniły się zmiany w zakresie korzystania z różnych źródeł informacji, które w większym stopniu zaspokajają potrzeby uczniów, niż materiały szkolne (por. tab. 7).

Rozkład odpowiedzi na pytanie:

Tabela 7

„W jaki sposób uzyskujesz w sytuacji zamknięcia szkoły aktualne informacje

o szkolnych zadaniach, lekcjach, wydarzeniach?"Odpowiedzi „tak” (uczniowie)

\begin{tabular}{|l|c|c|}
\hline $\begin{array}{c}\text { W jaki sposób uzyskujesz w sytuacji } \\
\text { zamknięcia szkoły aktualne informacje } \\
\text { o szkolnych zadaniach, lekcjach, } \\
\text { wydarzeniach? }\end{array}$ & I. pomiar & $\begin{array}{c}\text { II. pomiar } \\
\text { - zmiana względem } \\
\text { pomiaru I. }\end{array}$ \\
\hline $\begin{array}{l}\text { Informacje i zadania rozsyłane przez na- } \\
\text { uczycieli przez dziennik elektroniczny }\end{array}$ & $73,76 \%$ & $65,79 \%$ \\
$-7,97 \%$
\end{tabular}




\begin{tabular}{|l|c|c|}
\hline $\begin{array}{l}\text { Informacje i zadania przekazywane pod- } \\
\text { czas spotkań i zajęć prowadzonych zdal- } \\
\text { nie przez nauczycieli }\end{array}$ & $40,79 \%$ & $\begin{array}{l}43,16 \% \\
+2,37 \%\end{array}$ \\
\hline $\begin{array}{l}\text { Informacje rozsyłane przez kolegów po- } \\
\text { przez wspólną listę mailową }\end{array}$ & $20,72 \%$ & $25,26 \%$ \\
\hline $\begin{array}{l}\text { Informacje i zadania umieszczane przez } \\
\text { kolegów w Messengerze/WhatsAppie/ }\end{array}$ & $32,57 \%$ & $35,26 \%$ \\
Google Meet & & $+2,69 \%$ \\
\hline Indywidualne rozmowy telefoniczne - & $5,26 \%$ & $7,37 \%$ \\
dzwoni do mnie szkoła & & $+2,11 \%$ \\
\hline
\end{tabular}

Źródło: opracowanie własne.

Obszary nieobecne w narracjach wskazują możliwe kierunki rozwoju kompetencji cyfrowych. Zadbanie o rozbudzenie świadomości bezpieczeństwa i prawne aspekty wykorzystywania zasobów internetowych wydaje się być najważniejszym postulatem. Badani nauczyciele w czasie prowadzenia przez nich kształcenia zdalnego wyraźnie wskazali, że o ile przekazywanie w tym czasie wiedzy szkolnej nie było aż tak trudne, o tyle utrudnione było realizowanie funkcji wychowawczej, a prawie niemożliwe opiekuńczej ${ }^{14}$. Szkoły z dnia na dzień musiały przejść w tryb zdalny, skupiły się na wiedzy i kanałach jej przekazywania - a także oceniania, egzaminowania. $Z$ jednej strony jest to zrozumiałe $w$ trybie nagłych zmian, $\mathrm{z}$ drugiej - o nadmiernym skupieniu się w myśleniu o szkole na funkcji edukacyjnej pedagodzy mówią nie od dziśs ${ }^{15}$. Dbanie o relacje, jak podkreślają Jacek Pyżalski i Wiesław Poleszak, powinno stanowić priorytet w sytuacji konieczności odbywania edukacji zdalnej i wyprzedzać skuteczną dydaktykę ${ }^{16}$. Gdyby epizody nauczania zdalnego miały się powtarzać, konieczne jest znalezienie sposobów na wzmożoną pracę opiekuńczo-wychowawczą szkoły także w tych warunkach $^{17}$, uwzględniającą również wątki etyczne, związane z używaniem nowych technologii.

${ }^{14}$ S. Jaskulska, B. Jankowiak, Kształcenie na odległość w Polsce w czasie pandemii COVID-19. Raport, https:// sites.google.com/view/ksztalcenie-pandemia-raport [dostęp: 09.09.2020].

${ }^{15}$ Zob. R. Nawrocki, Edukacja jako pole gry, [w:] Twierdza. Szkoła w metaforze militarnej. Co w zamian?, red. M. Dudzikowa, S. Jaskulska, Warszawa 2016; M. Żytko, Edukacja w ramionach standaryzacji - czy autonomia jest jeszcze możliwa?, Czas Kultury, 2020, 1.

${ }_{16}$ J. Pyżalski, W. Poleszak, Relacje przede wszystkim - nawet jeśli obecnie jedynie zapośredniczone, [w:] Edukacja w czasach pandemii wirusa COVID-19. Z dystansem o tym, co robimy obecnie jako nauczyciele, red. J. Pyżalski, Warszawa 2020; tychże, Psychologiczna sytuacja dzieci i młodzieży w czasie epidemii, [w:] Tamże.

${ }^{17}$ M. Turczyk, S. Jaskulska, Ksztatcenie na odległość a prawa dziecka - nowe wymiary szkolnej ekskluzji w czasach epidemii COVID-19, Edukacja Elementarna w Teorii i Praktyce, 2020 (w druku). 


\section{W kierunku nowej szkoły}

Zebrane dane pozwalają na postawienie wniosków i predykcji, także o nachyleniu praktycznym. Diagnozowana zmiana w edukacji poza wymiarem technicznym - większe wykorzystanie narzędzi cyfrowych - kształcenia na odległość ma też bardzo wyraźny wymiar ludzki. Właśnie w obszarze kompetencji cyfrowych, ale też postaw wobec przejawów technicyzacji edukacji, obserwujemy wyraźne przemiany. Wykorzystanie potencjału, który się wytworzył, jest zadaniem szkoły (bliskiej) przyszłości równie ważnym, jak wypracowanie strategii działania w razie kolejnych epizodów przechodzenia $\mathrm{w}$ tryb zdalny.

Z prezentowanych $\mathrm{w}$ tym tekście wyników badań jawi się obraz zdalnej szkoły, która bazowała na zastanych kompetencjach uczniów i uczennic (w obszarze ich kompetencji nie zaszła duża zmiana) oraz stosowanych przedtem sposobach działania tyle, że z wykorzystaniem narzędzi cyfrowych. Nowa forma pracy nie zmieniła tego, że hasło "szkoła” wypełnia głównie przekazywanie/wyszukiwanie/przyswajanie informacji. Komunikacja dominowała nad współpracą, praca była raczej indywidualna, niż grupowa. Analizując wyniki badań, na pewno można powiedzieć o wzroście kompetencji cyfrowych dorosłych - $\mathrm{w}$ prezentowanych tu badaniach rodziców, innych nauczycieli. Oznacza to, że ogólnie rzecz biorąc, w zakresie kompetencji cyfrowych osób tworzących szkołę nastąpiła zmiana i należy ją wykorzystać. Wypracowanie koncepcji szkoły gotowej na kształcenie zdalne, lub przynajmniej hybrydowe, wykraczające poza przekazywanie wiedzy, jest koniecznością. Ale to nie jedyny wniosek. Wzrost kompetencji cyfrowych, ale też wyraźne wskazanie ich niezwykłej wagi oraz międzyludzkiego wymiaru, to wartości, które powinny zmieniać szkołę. Programowanie i wykorzystywanie różnych narzędzi cyfrowych w procesie edukacyjnym, szkolenia w tym zakresie nauczycieli i nacisk na współpracę oraz pracę grupową (online i offline), to możliwe i potrzebne kierunki tych zmian. Wykorzystywanie zasobów internetowych, materiałów interaktywnych, czy różnych aplikacji w codzienności szkoły stacjonarnej może przełożyć się na jej większą gotowość do wyzwań trybu zdalnego (gdyby znów zaistniała taka konieczność), a także pozwoli podtrzymać i dalej rozwijać zasoby kompetencji cyfrowych, które się zwiększyły, a w przypadku uczniów, które uzyskały nowe, szkolne zastosowanie.

Ważnych wskazówek dla myślenia o szkole bliskiej i dalekiej przyszłości dostarczają też obszary nieobecne $\mathrm{w}$ narracjach badanych przez nas rodziców. Zadbanie o rozbudzenie świadomości bezpieczeństwa i prawne aspekty wykorzystywania zasobów internetowych wydaje się w tym kontekście najważniejszym postulatem. Z innych badań wiemy, że nauczyciele wyraźnie 
wskazali, iż o ile przekazywanie w czasie edukacji zdalnej wiedzy szkolnej nie było aż tak trudne, o tyle utrudnione było realizowanie funkcji wychowawczej, a prawie niemożliwe opiekuńczej ${ }^{18}$. Szkoły z dnia na dzień musiały przejść w tryb zdalny, skupić się na wiedzy i kanałach jej przekazywania - a także oceniania, egzaminowania. $Z$ jednej strony jest to zrozumiałe $\mathrm{w}$ trybie nagłych zmian, z drugiej - o nadmiernym skupieniu się w myśleniu o szkole na funkcji edukacyjnej pedagodzy mówią nie od dziś. Gdyby epizody nauczania zdalnego miały się powtarzać, konieczne jest znalezienie sposobów na wzmożoną pracę opiekuńczo-wychowawczą szkoły także w tych warunkach, uwzględniającą również wątki etyczne, związane z używaniem nowych technologii, a także z budowaniem klimatu szkoły jako współpracującej wspólnoty, niezależnie od trybu jej działania.

Podziękowania. Pani Małgorzacie Łukianow pragniemy podziękować za opracowanie danych ilościowych.

\section{BIBLIOGRAFIA}

Jaskulska S., Jankowiak B., Postawy nauczycielek i nauczycieli wobec ksztatcenia na odległość w czasie pandemii COVID-19, Studia Edukacyjne, 2020, 57.

Jaskulska S., Jankowiak B., Ksztatcenie na odległość w Polsce w czasie pandemii COVID-19. Raport, https:/ / sites.google.com/view/ksztalcenie-pandemia-raport.

Kielar M.B., Gop A., Integralny Pluralizm Metodologiczny. Teoria i badania naukowe, Wydawnictwo Akademii Pedagogiki Specjalnej, Warszawa 2012.

Kompetencje cyfrowe, https://www.gov.pl/web/cyfryzacja/kompetencje-cyfrowe.

Krauze-Sikorska H., Klichowski M., Jaskulska S., Jankowiak B., Sikorska J., Koziarski J., Twoja lekcja w przyszłości. Jak wyobrażasz sobie naukę w szkole po pandemii COVID-19? Raport z badania ankietowego, VULCAN. https://sites.google.com/view/twoja-lekcja -w-przyszlosci.

Łukianow M., Gop A., Skrzypowska J., Rodzicielskie doświadczenia nauczania zdalnego w okresie pandemii COVID-19, Kultura i Społeczeństwo (w druku).

Nawrocki R., Edukacja jako pole gry, [w:] Twierdza. Szkoła w metaforze militarnej. Co w zamian?, red. M. Dudzikowa, S. Jaskulska, Wolters Kluwer, Warszawa 2016.

Pyżalski J., Poleszak W., Psychologiczna sytuacja dzieci i młodzieży w czasie epidemii, [w:] Edukacja w czasach pandemii wirusa COVID-19. Z dystansem o tym, co robimy obecnie jako nauczyciele, red. J. Pyżalski, EduAkcja, Warszawa 2020.

Pyżalski J., Poleszak W., Relacje przede wszystkim - nawet jeśli obecnie jedynie zapośredniczone, [w:] Edukacja w czasach pandemii wirusa COVID-19. Z dystansem o tym, co robimy obecnie jako nauczyciele, red. J. Pyżalski, EduAkcja, Warszawa 2020.

Turczyk M., Jaskulska S., Kształcenie na odległość a prawa dziecka - nowe wymiary szkolnej ekskluzji w czasach epidemii COVID-19, Edukacja Elementarna w Teorii i Praktyce, 2020 (w druku).

${ }^{18}$ S. Jaskulska, B. Jankowiak, Postawy nauczycielek i nauczycieli wobec ksztatcenia na odległość w czasie pandemii COVID-19, Studia Edukacyjne, 2020, 57. 
Vuorikari R., Punie Y., Carretero Gomez S., Van Den Brande G., DigComp 2.0: The Digital Competence Framework for Citizens. Update Phase 1: the Conceptual Reference Model, Luxembourg Publication Office of the European Union; https:/ / publications.jrc.ec.europa.eu/repository/bitstream/JRC101254/jrc101254_digcomp \% 202.0\%20the \% 20 digital \%20competence $\% 20$ framework $\% 20$ for $\% 20$ citizens. $\% 20$ update $\% 20$ phase $\% 201$. pdf.

Żytko M., Edukacja w ramionach standaryzacji - czy autonomia jest jeszcze możliwa?, Czas Kultury, 2020, 1. 